\title{
SAMA BAJAU DISPERSALS TO SABAH
}

\author{
Stephen Chia \\ Centre for Global Archaeological Research \\ Universiti Sains Malaysia, Penang \\ (stephen@usm.my) \\ DOI: https://doi.org/10.22452/brj.sp2019no1.1
}

\begin{abstract}
This paper discusses the archaeological evidence related to the early dispersals of the Sama Bajau, an Austronesian language speaker to Sabah, Malaysia. A brief review of the current archaeological data and findings will be presented and discussed along with the various issues and problems of the present state of knowledge and views on the Austronesian diaspora in Sabah. The Sama Bajau is an indigenous group of Austronesian language speakers residing in the Sulu-Sulawesi Seas and beyond. Many archaeologists and scholars believed that the Sama Bajau together with the other indigenous ethnic groups in Southeast Asia are the descendants of the Austronesians who migrated to Sabah and elsewhere in Island Southeast Asia and the Pacific region since the Neolithic period, dated 3,000-4,500 BP.
\end{abstract}

Keywords: archaeological research, Sama Bajau, Austronesian, Sabah, Neolithic

\section{Introduction}

Archaeological research and discoveries in Sabah, Malaysian Borneo since the late 1950s have provided ample evidence for the arrivals and existence of prehistoric human societies and cultures dated from the Palaeolithic to Neolithic and early historical periods (Chia, 2006, 2017). The archaeological evidence is found mostly in cave or rockshelter sites, and occasionally open-air sites. Hunter-gatherer societies arrived and occupied Malaysian Borneo during the Palaeolithic period as indicated by evidence found in Niah Caves (Harrisson, 1958; Majid, 1982; Barker et al., 2002) and Gua Sirih (Datan, 1993) in Sarawak as well as the sites of Tingkayu, Madai, Hagop Bilo, Tomanggong, Balambangan, Gua Samang Buat and Mansuli in Sabah (Harrisson \& Harrisson, 1971; Bellwood, 1988; Abdullah, 2013). These early sites contained mostly stone tools, faunal remains and sometimes human remains. At the West Mouth, Niah Caves, the earliest Homo sapiens skull in Malaysia was discovered and radiocarbon dated to around 40,000 BP (Harrisson, 1959; Barker et al., 2002). Some scholars have affiliated this so-called 'Deep Skull' to the early inhabitants of Australia and mainland East Asia, often known as the Australo-Melanesian (Brothwell, 1960; Wu, 1987; Krigbaum \& Datan, 2005). More intact and complete flexed burials were also found in 
West Mouth, dated to the late Palaeolithic, perhaps as early as 20,000 years ago (Harrisson, 1967; Brooks, Heglar, \& Brooks, 1979). Another site with AustraloMelanesian human remains dated about 16,000 bp is located on Balambangan Island, Kudat, Sabah (Ignatius, 2000; Majid et al., 1998).

The focus of this paper, however, is on the later period of human arrivals in Sabah, traditionally known as the Neolithic period, which is believed to occur around 3,000-4,500 BP based on the discoveries of technologically-new archaeological artifacts such as earthenware pottery, polished stone adzes, stone bark beaters as well as shell or stone ornaments and food remains. Burial practice during this period is characterized by extended burial as opposed to flexed burial during the earlier Palaeolithic period. Neolithic sites are usually found on the top layers of cave and rock shelter sites representing either burials, habitation or camp sites. Many scholars believed that the Austronesian language speakers are the carriers of this Neolithic culture and the descendants of the Austronesians who migrated to Island Southeast Asia since the Neolithic period, dated 3,000-4,500 BP. The Sama Bajau is one of the indigenous groups of Austronesian language speakers residing in the Sulu-Sulawesi Seas and beyond today.

\section{Austronesian arrivals and existence in Sabah}

The Austronesian language family covers about 1200 languages spoken by populations that inhabit more than half the globe, from Madagascar in the west to Easter Island (Pacific region) in the east and from Taiwan-Micronesia in the north to New Zealand in the south. The Austronesian dispersal is one of the most dynamic series of events in the Holocene prehistory in Southeast Asia and Oceania which is associated initially with a spread of Neolithic technology and culture as well as rice agriculture (Bellwood, 2016).

In Sabah, a majority of the archaeological evidence dated to the Neolithic period can be seen as small-scale migrations of Austronesian language speakers to Sabah (Chia, 2016a). The archaeological evidence also suggested that the Austronesian migrations, perhaps on a larger scale, occurred after the Neolithic period, that is during the later Metal or early historical periods, as indicated by many more sites with cultural materials such as metal artifacts, megaliths and wood coffin burials in Sabah. Some of these cultures such as the wood coffin burial tradition had continued until today (Chia, 2013).

Archaeological sites which can be connected to early Austronesian migrations include mostly sites from eastern Sabah such as Bukit Tengkorak, Melanta Tutup, Bukit Kamiri, Agop Atas, Agop Sarapad, Hagop Bilo, Pusu Samang Tas and Pusu Lumut. The earliest evidence of Austronesian arrivals, thus far, is on the coast of Semporna Peninsula in eastern Sabah, radiocarbon dated as early as 3,300-3,000 BP and represented by the coastal sites of Bukit Tengkorak (Bellwood, 1988; Chia, 1997, 
2001, 2003a, 2003b, 2005a, 2005b, 2006, 2008, 2009, 2015, 2016a, 2016b; Vandiver \& Chia, 1997), Bukit Kamiri and Melanta Tutup (Chia, 2008, 2009, 2016a; Eng \& Chia, 2010; Chia \& Matsumura, 2007; Chia, Arif, \& Matsumura, 2005; Albert, Bujeng, \& Chia, 2017). The finds and dating at these sites are typical of most Austronesian sites in Island Southeast Asia. Further away from the coastal areas of eastern Sabah, sites linked to the Austronesian movements include the limestone cave sites of Agop Atas, Agop Sarapad, Hagop Bilo, Pusu Samang Tas which produced mainly paddle impressed pottery and some red-slipped pottery as well (Harrisson \& Harrisson, 1971; Bellwood, 1988). All these potteries have a variety of impressed and incised designs which are very similar to those found in other Austronesian sites in Island Southeast Asia (Chia, 2003b, 2005b, 2006, 2007). Palaeoanthropological studies and comparison of human remains in Semporna with other human remains from contemporaneous sites in Southeast Asia also suggested widespread migrations of ancient populations during the Neolithic and Metal Age (Chia \& Matsumura, 2007; Chia et al., 2005).

In Semporna, archaeological research revealed ancient maritime-oriented societies who lived and produced pottery in this region as early as 3,300 years ago. Ethnoarchaeological research on the ancient pottery excavated from sites in Semporna indicated that these potteries are similar to the present Bajau traditional pottery in terms of types, functions, decorations and production techniques (Chia, 2003a; Narayanen, 2010; Chia \& Narayanen, 2017). In addition, the research has shown that the ancestors of the Bajau potters came from the southern Philippines and had made pottery for generations in Semporna (Narayanen, 2017). These parallels seemed to suggest that the Bajau pottery shared a similar pottery tradition with Bukit Tengkorak pottery tradition which dates back as early as 3,000 years ago in Semporna (Chia, 2003a).

\section{Discussion and summary}

In Sabah, the complexity of the history of Austronesian migrations and cultures to Malaysian Borneo had resulted in much controversies and debates on the origin, timing, identity and carrier of the Austronesian culture as well as the ethnogenesis of the indigenous people of Sabah. Nowadays, genomic research, ancient DNA and craniometrics studies are being employed to resolve such debates. However, many issues and questions remain to be answered before we can have a better understanding of the Austronesian dispersal to Sabah and Malaysian Borneo. As the data now stands, I am inclined to the idea that early small-scale Austronesian migrations and dispersals reached the eastern coast of Sabah by around 3300 BP via the islands of Philippines or Sulawesi (Chia, 2016c). Austronesian migrations to the west coast of Sabah and Sarawak, on the other hand, probably occurred after 2000 BP or later (Chia, 2016c). In a recent and comprehensive genetic study by Soares et al. (2016) using a combination of mitochondrial DNA, Y-chromosome and genome-wide data had shown a common 
ancestry for Taiwan/ISEA populations was established before the Neolithic and two minor late Holocene migrations, probably representing Neolithic input from both Mainland SEA and South China via Taiwan. The latter is believed to be responsible for the Austronesian language dispersal on small-scale migration and language shift rather than large-scale expansion of rice farmers (Soares et al., 2016). I believe that these small-scale migrations of Austronesians reached the coast of southeastern Sabah as indicated by the archaeological evidence found in Semporna, Sabah, and they are highly likely the ancestors of the Sama Bajau today. The earliest arrivals of Austronesians occurred on the coastal region of Semporna Peninsula, southeastern Sabah as suggested by archaeological evidence from the sites of Bukit Tengkorak, Melanta Tutup and Bukit Kamiri which have been radiocarbon dated from $3300 \mathrm{BP}$ to the Metal and historical periods (Chia, 2008). The archaeological evidence from these coastal sites also suggested that the early Austronesians were maritime-oriented or fisher-foragers societies. They conducted long-distance maritime trade or exchange on the east coast of Sabah as indicated by the occurrences of the Lapita pottery and obsidian from Melanesia found in Bukit Tengkorak, Bukit Kamiri and Melanta Tutup. This provided further evidence for the movements of people and trade items westwards, over a distance of 3,500 km, from Melanesia to eastern Sabah around 3000 BP (Chia, 2003c; Tykot \& Chia, 1997; Bellwood \& Koon, 1989). On the west coast of Sabah, however, there is thus far no archaeological evidence for the arrival of the Austronesian by 3000 BP, but there are however some indications from a few sites such as Pulau Burong and Sepirak Island that the Austronesians arrived much later during the Metal or early historical periods. Many archaeologists working in Southeast Asia, including the late Wilhelm G. Solheim II (2006) believed that the Sama Bajau is the direct descendant of the Nusantao (or the Austronesians) because their nomadic and maritime way of life paralleled the early Austronesians who inhabited the islands of Southeast Asia, including the east coast of Sabah. Genomic research and ancient DNA studies on the Austronesians are therefore crucial in order to understand the cultural roots, history, and ethnogenesis of the Sama Bajau as well as other indigenous societies in Sabah.

\section{Acknowledgements}

The author would like to thank the organisers of the International Conference on Sama/Bajau Maritime Affairs (ICONSAMA) 2018, in particular, the Department of Sabah Museum, Sabah State Archives, State Public Sector Training Institute, Universiti Malaysia Sabah and Universiti Malaya for the invitation and support to present this paper at the conference. This paper is the results of research carried out in Sabah for many years, and I wish to thank the Ministry of Education, Malaysia, Universiti Sains Malaysia and Sabah Museum Department for the support and cooperation. The most recent archaeological research in Sabah was funded by the Universiti Sains Malaysia 
Research University (RU) Grant under Grant Numbers 1001/PARKEO/870002 and 1001/PARKEO/870010.

\section{References}

Abdullah, J. (2013). Lembah Mansuli, Lahad Datu, Sabah dalam prasejarah Asia Tenggara. Pulau Pinang: Penerbit Universiti Sains Malaysia.

Albert, D., Bujeng, V., \& Chia, S. (2017). Analisis awalan sisa-sisa cangkerang moluska prasejarah akhir di Melanta Tutup dan Bukit Kamiri, Semporna, Sabah. Jurnal Arkeologi Malaysia, 30(1), 1-11.

Barker, G., Barton, H., Beavitt, P., Bird, M., Daly, P., Gilberston, D., Hunt, C., Krigbaum, J., Lewis, H., Manser, J., Mclaren, S., Paz, V., Piper, P., Pyatt, B., Rabett, R., Reynolds, T., Rose, J., Rushworth, \& G., Stephens, M. (2002). Prehistoric foragers and farmers in Southeast Asia: Renewed investigations at Niah Cave, Sarawak. Proceedings of the prehistoric society, 68, 147-164.

Bellwood, P. S. (1988). Archaeological research in southeastern Sabah. Kota Kinabalu: Sabah Museum.

Bellwood, P.S. (2016). Austronesian studies in 2016: Where are we now? In B. Prasetyo, T. S. Nastiti, \& T. Simantunjak (Eds.), Austronesian Diaspora: A New Perspective (pp 267-274). Yogyakarta: Gadjah Mada University Press.

Bellwood, P. S., \& Koon, P. (1989). Lapita colonists leave boats unburned. Antiquity, 63, 613-622.

Brooks, S. T., Heglar, R., \& Brooks, R. H. (1979). Radiocarbon dating and paleoserology of a selected burial series from the Great Cave of Niah, Sarawak, Malaysia. Asian Perspectives, 20, 21-31.

Brothwell, D. R. (1960). Upper Pleistocene human skull from Niah Caves, Sarawak. Sarawak Museum Journal, 9(15-16), 323-349.

Chia, S. (1997). Prehistory of Bukit Tengkorak as a major prehistoric pottery making site in Southeast Asia. Unpublished Ph.D. Thesis. Universiti Sains Malaysia, Penang, Malaysia.

Chia, S. (2001). The prehistory of Bukit Tengkorak, Sabah, Malaysia. Journal of Southeast Asian Archaeology, 21, 146-159.

Chia, S. (2003a). The prehistory of Bukit Tengkorak as a major prehistoric making site in Southeast Asia. Kota Kinabalu: Sabah Museum.

Chia, S. (2003b). Prehistoric pottery production and technology at Bukit Tengkorak, Sabah, Malaysia. In J. Miksic (Ed.), Earthenware in Southeast Asia (pp. 187-200). Singapore: Singapore University Press.

Chia, S. (2003c). Obsidian sourcing at Bukit Tengkorak, Sabah, Malaysia. Sabah Society Journal, 20, 45-64. 
Chia, S. (2005a). Prehistoric earthenware of Malaysia. Journal of Sophia Asian Studies, 23, 201-235.

Chia, S. (2005b). Archaeological research in Semporna, Sabah. Test Pit Chronicle of the University of the Philippines Archaeological Studies Program, 6, 18-22.

Chia, S. (2006). Archaeological evidence of early human occupation in Malaysia. In T. Simantunjak, I. H. E. Pojoh, \& M. Hisyam (Eds.), Austronesian diaspora and the ethnogeneses of people in Indonesian archipelago: Proceedings of the international symposium (pp 239-260). Jakarta: Indonesian Institute of Social Science.

Chia, S. (2007). The Metal Age in Malaysia. In M. Saidin \& S. Chia (Eds.), Archaeological heritage of Malaysia (pp 109-123). Penang: Pusat Penyelidikan Arkeologi Malaysia, Universiti Sains Malaysia.

Chia, S. (2008). Prehistoric sites and research in Semporna, Sabah, Malaysia. Bulletin of the Society for East Asian Archaeology (BSEAA), 2, 1-7 Retrieved from http://www.seaa-web.org

Chia, S. (2009). Recent archaeological discoveries in Semporna, Sabah, Malaysia. In S. Mokhtar S \& A. R. Kamarudin (Eds.), Proceedings of the International Seminar on Sharing Our Archaeological Heritage (pp 203-212). Johor Bahru: Yayasan Warisan Johor.

Chia, S. (2013). Wood coffin burials in Kinabatangan, Sabah. Penang: USM Press.

Chia, S. (2015). Archaeological research in 2007 at Bukit Tengkorak, Semporna, Sabah. Sabah Society Journal, 31, 37-60.

Chia, S. (2016a). History of archaeology in Sabah. In P. K. Lim (Ed), North Borneo: A collective history (pp. 13-24). Kota Kinabalu: Opus Publications.

Chia, S. (2016b). Arkeologi Bukit Tengkorak, Sabah. Penang: Pusat Penyelidikan Arkeologi Global, USM Press.

Chia, S. (2016c). Austronesian dispersal to Malaysian Borneo. In B. Prasetyo, T. S. Nastiti, \& T. Simantunjak (Eds.), Austronesian diaspora: A new perspective. Proceedings of International Symposium on Austronesian Diaspora (pp. 267-274). Yogyarkarta: Gadjah Mada University Press.

Chia, S. (2017). A history of archaeology in Malaysia. In J. Habu, P. Lape, J. Olsen, \& Jing Z. (Eds.), Handbook of East and Southeast Asian archaeology (pp. 125-142). New York: Springer Press.

Chia, S., \& Matsumura, H. (2007). Late prehistoric burials at Melanta Tutup, Semporna, Sabah. In Archaeological studies on cultural diversity in Southeast Asia and its neighbors (pp. 361-370). Tokyo: Sophia University.

Chia. S., \& Narayanen, S. (2017). On the origin of Bajau pottery tradition in Semporna, Sabah. In Mohd. Anis Md. Nor (Ed.), Perspectives on Bajau/Sama' diaspora (pp. 123-131). Kota Kinabalu: Department of Sabah Museum.

Chia, S., Arif, J., \& Matsumura, H. (2005). The dental characteristics of prehistoric human teeth from Melanta Tutup, Semporna, Sabah. In Z. Majid (Ed.), Perak Man and other prehistoric skeletons in Malaysia (pp. 239-253). Penang: USM Press. 
Datan, I. (1993). Archaeological research at Gua Sireh (Serian) and Lubang Angin (Gunung Mulu National Park), Sarawak, Malaysia (Sarawak Museum Journal, Special Monograph No. 6). Kuching: Sarawak Museum.

Eng, K. K., \& Chia, S. (2010). Pengkebumian prasejarah lewat di Bukit Kamiri,

Semporna, Sabah. In S. Chia \& H. Isa (Eds.), Archaeological heritage of Malaysia

Vol. 3 (pp. 44-58). Penang: Pusat Penyelidikan Arkeologi Malaysia, Universiti Sains Malaysia.

Harrisson, B. (1967). A classification of stone age burials in the Niah Great Cave, Sarawak. Sarawak Museum Journal, 15(30-31), 166-198.

Harrisson, T. (1958). The caves of Niah: A history of prehistory. Sarawak Museum Journal, 8(12), 549-595.

Harrisson, T. (1959). Radiocarbon - C14 dating B.C. from Niah: A note. Sarawak Museum Journal, 9(13-14), 326-332.

Harrisson, T., \& Harrisson, B. (1971). The prehistory of Sabah. Kota Kinabalu: Sabah Society.

Ignatius, J. (2000). Pulau Balambangan dan sumbangannya kepada Zaman Paleolitik Akhir di Asia Tenggara. Unpublished Master of Arts dissertation, Universiti Sains Malaysia, Penang, Malaysia.

Krigbaum, J., \& Datan, I. (2005). The Deep Skull and associated human remains from

Niah Cave. In Z. Majid (Ed.), The Perak Man and other prehistoric skeletons of Malaysia (pp. 131-154), Penang: USM Press.

Majid, Z. (1982). The West Mouth, Niah, in the prehistory of Southeast Asia. Kuching: Sarawak Museum.

Majid, Z., Ignatius, J., Tjia, H. D., \& Koon, P. (1998). Some interesting late Pleistocene - Early Holocene finds from excavations in Balambangan Island, Sabah. Sabah Society Journal, 15, 29-40.

Narayanen, S. (2010). Teknologi pembuatan tembikar tradisional di Tampi Kapur, Semporna, Sabah. Jurnal Arkeologi Malaysia, 23, 70-81.

Narayanen, S. (2017). Past and present pottery-making traditions in Malaysia: An ethnoarchaeological perspective. Unpublished Ph.D. thesis, Universiti Sains Malaysia, Penang, Malaysia.

Soares, A. P., Trejaut, J., Rito, T., Cavadas, B., Hill, C., Eng, K. K., Mormina, M., Brandao, A., Fraser, R. M., Wang, T-Y., Loo, J-H., Snell, C., Ko, T-M., Amorim, A., Pala, M., Macaulay, V., Bulbeck, D., Wilson, J. F., Gusmao, L., Pereira, L., Oppenheimer, S., Lin, M., \& Richards, M. B. (2016). Resolving the ancestry of Austronesian-speaking populations. Human Genetics, 135, 309-326.

Solheim II, W. G. (2006). Archaeology and culture in Southeast Asia: Unraveling the Nusantao. Diliman: University of University Press.

Tykot, R. H., \& Chia, S. (1997). Long-distance obsidian trade in Indonesia. In P. Vandiver, J. Druzik, J. Merkel, \& J. Stewart (Eds.), Materials issues in art $\mathcal{E}$ 
archaeology V, Materials Research Society Symposium Proceedings 462 (pp. 175180). Pittsburg: Material Research Society.

Vandiver, P., \& Chia, S. (1997). The pottery technology from Bukit Tengkorak, a 30005000 year-old site in Borneo, Malaysia. In P. Vandiver, J. Druzik, J. Merkel, \& J. Stewart (Eds.), Materials issues in art $\mathcal{E}$ archaeology V (pp. 269-277). Pittsburg: Material Research Society.

$\mathrm{Wu}$, X. (1987). Relation between Upper Paleolithic men in China and their southern neighbors in Niah and Tabon. Acta Anthropologica Sinica, 6, 180-183. 